\title{
ADVANCING HUMAN RIGHTS THROUGH THE UNITED NATIONS*
}

\author{
John W. Halderman†
}

I would like to suggest a means of contributing to the improvement of human rights observances by practical international action. Accomplishing this goal would require moving the world out of the rut of its traditional approach to the centrally important aspects of international relations. Human rights observances are part of this important complex of factors. To bring about such a change requires the thinking of some novel thoughts as well as persistence and dedicated effort. Progress would entail difficulties and perhaps some risk and sacrifice. If, however, the course of action I outline is practical, it follows that the risks and sacrifices will not be so great as to be unacceptable.

This proposal is concerned with the United Nations. It entails one of the novel thoughts - the necessity of rethinking the role and potential of the United Nations. It is desirable first to outline the nature of the human rights problem, which is the focus of our immediate attention.

International efforts to solve the human rights problem bear some resemblance to international efforts to solve the arms problem. I have been watching the latter efforts most of my life; I retain a strong recollection of the 1922 five-power naval treaty, which was supposed to be a breakthrough and a vindication of the role of World War $I$ as the war to end all wars. Since then, disarmament conferences have continued. The 1922 treaty was the last event that impressed me as a breakthrough. Since then, we have participated in and observed a variety of arms races, including the nuclear arms race still in progress.

International efforts to improve the observance of human rights started just after World War II and have grown in scope and in the apparent strength of measures taken. The result bears a resemblance, perhaps a family resemblance, to the result of arms control efforts. The twenty-fifth report of the Commission to Study the Organization of Peace, entitled New Aspects of the International Protection of Human Rights, says:

Framers of the United Nations Charter gave human rights a new international status and all signatories pledged themselves to promote universal respect for, and observance of, human rights. However, the record of these last thirty-two years gives cause for grave concern. A rapidly changing international community continues to witness atrocities and mass murders, as well as

* 01979 by John W. Halderman.

† Scholar in Residence, Duke University School of Law. 
the denigration of the dignity and worth of individuals and groups. . . The practice of torture is widespread, the incidence of terror has never been greater ... [G]ross violations of human rights around the world virtually rival the totalitarian excesses of the interwar years and patently demonstrate that the peoples of the United Nations have not yet made good on their promise to promote basic human rights. ${ }^{1}$

In awarding the Nobel Peace Prize to Amnesty International, the Nobel Committee said:

[S]ince the Universal Declaration of Human Rights was adopted by the United Nations almost [thirty] years ago, positive forces have fought in many countries to evoke its ideals. But the world had during those years witnessed an increasing brutalization, an internationalization of violence, terrorism and torture. ...

There is a similarity between the problems of armaments and human rights not only in the results hitherto achieved in efforts to solve them, but also (a) in that neither can be solved unless the central problems of international relations are solved, and (b) in that the solution of these central problems must mean the solution of these two, among others.

An important difference between the two problems is that efforts to solve the armaments problem, per se, are not directed to the central problems whereas efforts to solve the human rights problem are. Trying to solve the armaments problem per se is like trying to cure a disease by treating the symptoms. The human rights problem, on the other hand, is not only a symptom of the disease but an integral part of it. The central problem is that humanity is divided into separate communities. Differing views of human rights result from this division.

A second difference between the armaments and human rights problems includes the fact that the former is clearly and essentially an international problem. No one would think of saying that it is essentially domestic. On the other hand, human rights practices are domestic in the important sense that they are frequently so regarded by the authorities and supporting populations responsible for them in particular countries. Regimes sometimes feel that their very survival is threatened by attacks on their human rights practices. Thus, when the United States was seen as demanding that South Africa institute democracy in the form of equal votes for all, the South African Prime Minister said:

[W] hereas, as it appears to us at the moment, the Soviets want to kill us off by force, the United States wants to strangle us with finesse. ${ }^{3}$

1. Commission to Study the Organization of Peace, New aspects of the International Protection of Human Rights 9 (25th Rep. 1977).

2. Hawk, For the Proection of Human Values, MatchBox, Fall 1977 , at 1 .

3. Interview with John Vorster, Prime Minister of the Republic of South Africa, A.B.C. News, Issues and Answers (Oct. 23, 1977). 
In some important cases, the United Nations has sought candidly to improve human rights practices in particular countries by forcing the removal of regimes in those countries. ${ }^{4}$ When I suggest that some human rights issues are essentially domestic I am not speaking in terms of technicalities (such as interpretations of the United Nations Charter), but in terms of how responsible authorities and concerned individuals feel sometimes about particular issues.

In summary, our efforts to solve the armaments problem per se, as a separate issue seem doomed because they are not aimed at the basic problem. Our efforts to solve the human rights problem are aimed in the right direction, but they encounter difficulties because of the intractable nature of that problem.

For our purposes we can identify two main categories of international activity. First is the political, largely concerned with the handling of disputes and situations. The second area of activity is designed to improve conditions of life. The United Nations Charter calls for activity in both categories. While political activity is more important to our thesis, I will touch first upon the latter.

Compared with the League of Nations Covenant (which called almost exclusively for dispute-handling activity), the United Nations Charter incorporates provisions for large new areas of activity in the economic, social, and related fields-including human rights. Charter programs for the advancement of human rights fall within this area. The organization is directed to promote "universal respect for, and observance of, human rights and fundamental freedoms." Member states are committed, "to take joint and separate action in cooperation with the organization for the achievement" of this purpose. ${ }^{6}$ Human rights are not singled out in the more specific program authorizations, which are applicable to the general economic, social and cultural area; and which are stated in general terms. They include: the making of reports and studies; recommendations to the General Assembly, to member states, and to specialized agencies; and the preparation of treaties and the holding of international conferences. ${ }^{7}$

These were intended to be broad and general programs directed to the generality of states. They were not intended as authorizations to put pressure on particular states for particular human rights practices. This intent was manifested, among other ways, in the modifications that were made in the domestic jurisdiction clause as it appeared in the League Covenant ${ }^{8}$ and carried into the Dumbarton Oaks Proposals. ${ }^{9}$ The modifications instituted in San

\footnotetext{
4. This reference to the Spanish and Rhodesian cases will be mentioned below.

5. U.N. Charter, art. 55.

6. Id. art. 56 .

7. Id. art. 62 .

8. League of Nations Covenant art. 15, para. 8.

9. Dumbarton Oaks Documents on International Organization (Rev.) (October 7, 1944) U.S. Dep't of State Conf. Ser. No. 60, Ch. VIII, $\$$ A, para. 7.
} 
Francisco insured that the new programs in the economic, social, human rights, and related fields could not cause the organization to intervene in the domestic affairs of states. The United States was instrumental in bringing about these modifications in the language of the clause and in its location in the Charter. ${ }^{10}$

The present United States administration says that "no member of the United Nations can claim that mistreatment of its citizens is solely its own business." 11 When states subscribed to the Charter, I am sure that they did not intend to open up their human rights practices to international scrutiny, criticism, and perhaps stronger measures. This situation may have changed. In any case, the matter falls into our discussion of political, or disputehandling activity. States do not invoke the domestic jurisdiction rule except to contest an action or avoid an anticipated measure. If the rule comes into issue, it is not important as a technicality, but as the result of how governments and people really feel about the matter in issue.

The Charter provisions authorizing human rights programs have given rise to considerable activity of which I believe the most important instance was the preparation and adoption of the Universal Declaration of Human Rights. This instrument does not purport to be more than a statement of aspiration, and this fact has contributed to the Declaration's effect in consciousnessraising in many parts of the world. There have been other pronouncements of similar character, on various aspects of human rights, and these, individually and collectively, have no doubt had beneficial consciousness-raising effects. However, they have tended to be obscured by their multiplicity and the Universal Declaration continues to stand out. From the outset, this document was considered the first step in an international bill of rights, which would be completed by a treaty of comparable scope. The treaty was to enumerate rights and to give them status as binding legal obligations. This projected treaty became the two Covenants: The Covenant on Civil and Political Rights and the Covenant on Economic, Social and Cultural Rights. ${ }^{12}$ These are in force in a number of states. ${ }^{13}$ This number includes the Soviet Union, some western democracies, and the United States President has asked for Senate advice and consent to their ratification. ${ }^{14}$ It is difficult to perceive how such treaties, purporting to commit parties of basically different systems (in which the differences definitely apply to attitudes about human rights) to

10. Doc. 1019, I/1/42, 6 U.N.C.I.O. Docs. 507 (1945).

11. Peace, Arms Control, World Economic Progress, Human Rights: Priorities of U.S. Foreign Policy, Address by President Carter to the U.N. General Assembly (March 17, 1977) reprinted in 76 Dep't State Bull. 329, 332 (1977).

12. G.A. Res. 2200, 12 U.N. GAOR, Supp. (No. 16) 49, U.N. Doc. A/6316 (1966).

13. After 30 Years, an International Bill of Human Rights, 13 U.N. CHron. 50 (April 1976).

14. Remarks on Signing International Covenants on Human Rights, 13 WEekLy Comp. OF Pres. Doc. 1488 (Oct. 10, 1977); President Carter Signs Covenants on Human Rights, 77 DeP'T StaTE BuLl. 586, 587 (1977). 
such a broad range of rights, can represent a true meeting of the minds. In a press conference of April 7, 1977, the retiring director of the United Nations Human Rights Division was asked whether, in adherences to the Covenants, hypocrisy was not the rule rather than the exception and whether, for example, there was more torture than before the Covenants were signed. The answer did not deny this suggestion, but expressed hope that the Covenants would provide new possibilities for improving human rights practices. ${ }^{15}$

Personally, I doubt that this will be the case. I was part of the team that worked on both the Universal Declaration and the proposed covenant in its early phase in the United States. I dropped out in mid-1948 when work on the Universal Declaration was completed, since the work would henceforth concentrate on the Covenant, which I did not feel was an effective way of advancing human rights. I still hold this opinion and believe I have acquired a better comprehension of the true nature of the change that will be required to this end, and the difficulty of bringing it about. Such treaties are, in the first place, essentially irrelevant. ${ }^{16}$ Secondly, a dispute over human rights may be more exacerbating if a treaty is involved than otherwise, because then either party can accuse the other of violating the treaty. ${ }^{17}$ Between communist countries and western democracies, efforts to implement the treaties can give rise to interpretation disputes. For this reason the main significance of the treaties may prove to be in the area of international activity concerned with the handling of disputes rather than in the more placid one I have discussed concerning improved conditions of life. A third disadvantage of such treaties is that they convey the illusion of being a means of progress, and thus distract attention and effort from channels that might prove more fruitful, or even the search for such channels.

The Charter provisions on human rights represent the outcome of efforts by a number of able and dedicated people to enable the new organization to attack the problem directly and to carry out programs that would actually improve the observance of human rights throughout the world. These people would have liked stronger provisions in the Charter than are actually there. What we have represents the maximum upon which agreement could be reached. The resulting provisions form part of the program designed to improve conditions of life, and it was anticipated that they would be non-

15. Mr. Schreiber Discusses Achievements of United Nations in Field of Human Rights, 14 U.N. Chron., May 1977, at 39, 40.

16. This statement is premised on he apparent unlikelihood that such comprehensive treaties can solve problems which are essentially aspects of the central problem of international relations. A parallel case from this perspective is the General Treaty for the Renunciation of War as an Instrument of National Policy (August 27, 1928), 46 Stat. 2343, T.S. No. 796, 94 L.N.T.S. 57.

17. This statement assumes that if parties to the covenants desire to accuse other parties of violations of human rights, they will not normally be restrained by the restricted provisions for handling such complaints contained in these instruments. This assumption would seem justified by the freedom with which the United Nations has been caused to exceed its Charter limitations as to the handling of disputes. This matter will be discussed further below. 
controversial. Organization proposals were to be aimed at the generality-not to particular states. The handling of human rights by individual states within their respective territories was considered, I believe, a matter of domestic jurisdiction and outside United Nations competence. However, in actuality, many complaints against individual states have been brought into the United Nations. This type of activity soon became a matter of controversy within the United Nations. Consideration of this subject brings us into the political arena of international activity.

The political area has greater potential for change compared with that concerned with improving conditions of life, because political controversy grips people's attention more than declarations of principle and programs for the improvement of economic and social conditions.

In moving to this area, we will leave behind the consideration of programs directed to the subject of human rights per se. The important potential of dispute-handling activity is found in central problems of international relations, such as those of world community, democracy, and peace; these obviously include human rights. If we could pursue this latter subject effectively by action directed to improve human rights per se, we would contribute to these broader goals, too. The problem is to find a practical channel to promote this interlinked set of goals. It seems to me that United Nations disputehandling functions and procedures constitute a channel. It is, in fact, the only one of which I am aware. Its goal may be best described as the building of world community sentiments. It is calculated to do this essentially by democratic means. The process would build democracy and would, accordingly, be conducive to the improvement of human rights observances as understood by democratic societies.

My study of United Nations political activity has persuaded me of the validity of several conclusions. First, we have been in error since World War I in trying to achieve world peace and security by evolving means of solving the disputes that arise under the traditional format of international relations. Of course, dispute-handling was not the only road envisaged to this goal. It was hoped that activities in the human rights area and, more generally, in those of economic and social conditions, in regard to the strengthening of international law and the control of armaments, would contribute to conditions of peace. However, these programs were considered essentially peripheral, at least by ultimate decision makers. The core of political relations, involving the emergence and handling of disputes and situations, was expected to continue unchanged except that the United Nations was expected to be able to handle all disputes successfully, either by negotiations or, if necessary, by the application of sanctions. In this perspective, when most people thought about means of achieving peace and security per se, they thought in terms of methods of peacefully settling disputes. It is, however, impossible to devise methods of solving all disputes that arise under the traditional format of relations. We 
have not tried every means of dispute-settlement, but we have tried a considerable variety and combinations of different methods. It seems justifiable to conclude that, given the political world that exists, we will not do measurably better in the future. The system we have (or lack thereof) will give rise to intractable disputes and the occasional war. Therefore, we should turn our attention to the system itself and seek means of lessening the intensity of disputes so that they will be manageable. Stated affirmatively, this would mean building world community to the requisite degree.

My second conclusion is that the kind of community needed is not among governments or states, but must be among the peoples of the world or the informed elements of the world population. At least, there is no way to my knowledge of bringing about the desired degree of community among governments apart from their populations. However, community bonds can extend beyond national boundaries and among different national populations. When this fabric exists to the requisite degree, it exerts the necessary control over governments to assure sufficiently consistent policies for the maintenance of peace. It was, I am convinced, the existence of such community sentiments among the Scandinavian countries and Finland that permitted the peaceful solution, in this century, of such potentially severe disputes as the separation of Sweden and Norway, the Aland Islands case and the Eastern Greenland case. It may seem that the goal of such a degree of world community is so remote that it is worthless to think about. As I see it, however, we do not have much choice but to think about it.

The third conclusion is that the United Nations Charter outlines procedures which, if followed within limitations agreed to by all concerned as applicable to themselves, could contribute significantly to this goal. This would require to an increasing extent, of course, that significant disputes be brought into the organization if not promptly settled and handled there according to these procedures.

The United Nations dispute-handling function basic to this end is that of peaceful settlement, which has to do with the organization's role in finding agreed solutions of substantive issues in dispute. Its potential in this respect has been overlooked because states have not been interested in longer range objectives, but only in the traditional approach of pursuing policy goals as immediately and often superficially perceived.

One consideration has been that, from the beginning, the peaceful settlement function has been overshadowed by collective measures, often called the enforcement power of the organization. It might be useful at this point to describe the two functions from the perspective of this discussion.

Primary importance was attached to collective measures because it was supposed to correct the deficiency of the League of Nations which had brought about its failure to prevent World War II, namely the inability to use force to put down aggressions. The collective measures function that was, accordingly, 
put in the Charter authorizes the Security Council to use force or lesser tangible pressures (such as economic or diplomatic sanctions) to deal with aggressions, other breaches of peace, or threats to peace.

The potential of the United Nations for the goals we are considering here lies in the use of powers given to it with the understanding that they are applicable to all, in real world situations. The collective measures function is not in this category. It was intended to apply to wrongdoers. Governments and peoples do not regard their own countries in this light.

Governments did, however, recognize that their countries might become involved in disputes and they wished to enable the new organization to assist in finding solutions. Simultaneously, they had no intention of giving up the attribute of traditional sovereignty, by which states reserve the right for themselves to be the final judge of matters of concern to themselves. The result was that both Council and Assembly were empowered to discuss disputes and make recommendations for their solution. However, United Nations political organs have appeared in numerous situations to do more than recommend solutions of disputes on their merits. Such measures were not, however, agreed to in the Charter. There was no authorization of legally binding decisions and consequently, none for the enforcement of such decisions. Similarly, there is no authorization of demands or condemnations. The basic limitation to discussion and recommendation was agreed to almost tacitly and without debate at the same time as predominant attention was being given to the collective measures function.

The present proposal is that governments concerned about improving human rights as well as in achieving permanent world security should support strenuously the United Nations handling of all significant disputes within the limits of the Charter provisions. If this could be accomplished, or seen to be accomplished to a significant extent, it would be the first time since the beginning of the modern state system that major powers would be seen to exercise uniform restraints, in accordance with an agreed upon plan, in the conduct of their international relations. The traditional approach has been characterized by freedom of governments to apply any available pressures that they deem appropriate in the pursuit of their policy objectives. Therefore it is essentially anarchic. It is difficult to foresee change taking place unless some mediating agency blunts the sharp edges of direct state-to-state relations in disputed situations. The United Nations has the general qualifications to meet this requirement. In particular, it has the peaceful settlement function incorporating restraints agreed to by all concerned with the conscious anticipation that it would be applicable to themselves in disputes that might arise in the future.

The potential of this process lies in bringing important international disputes into the United Nations and in improving the debating process involved in their consideration. These debates could be expected to become more full and free as parties realize that no powers would be asserted beyond 
those they, themselves, had agreed to. Relations would relax and confusion would lessen as people came to understand the nature of the powers being exercised. Fuller and freer debates are more likely to concentrate on the true issues rather than on propaganda issues; to consider rationally proposals offered as solutions; and to select the best of these. Thus, debates would come to fulfill gradually their inherent consensus-building role. The process is inherently democratic and could tend gradually to strengthen democracy world-wide. By the same token, human rights practices, as understood by democratic societies, would improve.

An elementary international system for handling disputes and situations thus was outlined in the Charter. As one part of the system, majorities in given disputes in the competent United Nations organ, would be bound to limit the organization to discussion and recommendation on the merits of the case. The party or parties on the other side would be bound to acquiesce in this procedure but would not be bound, morally or legally, to comply with any resulting recommendation. Introduction of the system could not be expected, for some time, to bring about solutions of all disputes. Parties on both sides of the case, as well as the other members of the competent organ, would be bound together in the debating process and this, over a series of cases should have reprecussions in the broad reaches of the world's populations, with a gradual tendency to build world community sentiments.

The Charter framers drew a blueprint and built the essential parts of a system that had, and still might have, the capability of moving the world in the direction of peace and security, though not in the manner intended originally. For this potential to be realized, a vision is necessary, which, up to now, has been lacking. Essential to this realization would be equal and reciprocal application of the limitations on United Nations dispute-handling powers. These, however, were put into the Charter by statesmen motivated wholly by concern to protect their own countries from unwanted actions. They were not thought of, then or later, as intended for the protection of others. When the organization began to function, statesmen continued to pursue the traditional approach and utilized the United Nations dispute-handling resources as new means of pressure. If limitations on Charter powers would have hindered desired measures, they were overridden by one means or another.

One example was the Spanish human rights case, in the first year of United Nations operations. A General Assembly resolution ${ }^{18}$ said, in one paragraph, that the Franco regime of Spain should be replaced by one more concerned about human rights. In the next paragraph it recommended that member states withdraw their ambassadors and ministers from Spain. The impression conveyed was that the Assembly was initiating diplomatic sanctions to force a change of the Spanish regime-something it had never been empow-

18. G.A. Res. 39 (I), U.N. Doc. A/64/Add. 1, at 63 (1946). 
ered to do and a course of action which no government would accept as legitimate if applied against itself.

In such cases it is usual for governments and their representatives to offer technical justifications of the legality, under the Charter, of what is being done. In this case one justification was that the United Nations was merely recommending that states withdraw diplomatic representation from Spain and was thus staying within its powers under the Charter. Nevertheless, it appeared to the world that diplomatic sanctions were being applied. The purpose of the action was, it seems clear, to mobilize world opinion in support of such action and to persuade the Spanish government that this was being done. If statesmen of governments supporting the action had been challenged on the ground that public opinion was being confused, since no power had been given to the organization for this purpose of forcing the replacement of a government, the answer might well have been that this was unimportant, that governments and not public opinion were the actors under international law; that governments knew what was going on, and so there was no confusion in quarters where it would be important.

However, public opinion is important since here the consensus must be formed-the necessary consistency of thought patterns-which is the necessary substructure of any system capable of maintaining peace and security as well as assuring generally acceptable observances of human rights.

The Spanish case was the first in a series in which the United Nations has given the impression of deciding the merits of disputes. These cases include the early Palestine case and later aspects of it, including use of the Suez Canal and Israeli actions in Jerusalem; an important aspect of the Korean case; the Katanga case in the Congo; and numerous pronouncements and actions concerning human rights in southern Africa.

The latter include the sanctions in the Rhodesian case, which bear some resemblance to the measures in the Spanish case in having the apparent purpose of forcing a change or regime in order to secure the human rights of the inhabitants. In the Rhodesian case, of course, the tangible pressure was not the result of a mere recommendation to states that they apply the measures. It took the form of mandatory collective measures based on a finding that the situation was a threat to peace. ${ }^{19}$ However, resolutions, proposed resolutions and accompanying debates had conveyed the impression that the purpose of organizational activity in this case was the suppression of the secessionist regime. ${ }^{20}$ This was even suggested in the Council resolution initiating the collective measures. The result has been that the world has seen the sanc-

19. S.C. Res. 232, 4 U.N. SCOR 7, U.N. Doc. S/INF/2 I/Rev. 1 (1966).

20. Some of the relevant resolutions and draft resolutions are described, and the debates summarized in, The Question of Southern Rhodesia (1965) U.N.Y.B. 117-34 (1967); The Situation in Southern Rhodesia (1966) U.N.Y.B. 94-117 (1968). 
tions as having the purpose of overthrowing the regime, ${ }^{21}$ even though no government would accept for itself the power of the organization to do this.

This is a difficult case and was so recognized at San Francisco. Special pains were taken there to make clear in the record that the functions of peaceful settlement and collective measures were not to be confused in these circumstances. ${ }^{22}$

It may seem that the case is not only difficult, but remote from our subject. It should be recalled, perhaps, that the proposal under discussion would seek to build world community in a democratic way, and thus improve the observance of human rights, through enabling debates on international issues to perform their rightful consensus-building role. This cannot occur unless parties to disputes feel that they are being subjected only to powers they have agreed to as acceptable and unless, moreover, the nature of the powers being exercised are generally understood by governments and peoples. It is incumbent in a case like the Rhodesian one that every effort be made to make clear to all concerned that sanctions are being employed only to deal with a threat to peace, and that United Nations pronouncements on the merits are recommendations only. The fact that such clarifications might have to be made in highly political and emotional atmospheres is but one measure of the difficulties that can be expected if significant progress toward world security is to be made by this method.

Moving away from such extreme goals as the overthrow of regimes by United Nations measures, lesser instances of purported decisions by the organization on substantive issues are commonplace, in human rights cases as in others.

A 1968 report of a special rapporteur of the Human Rights Commission stated that in situations showing consistent patterns of gross violation,

If dialogue and negotiation fail to prove effective, the mobilization, on a world-wide scale of international condemnation and as a final resort the application of international sanctions, both economic and, if necessary and expedient, military, should be undertaken. . . . ${ }^{23}$

21. That the General Assembly shared this view is indicated by G.A. Res. 2262, 12 U.N. GAOR, Supp. (No. 16) 45, U.N. Doc. A/6716 (1967). To similar effect see, Introduction to the Annual Report of the Secretary-General on the Work of the Organization, 16 June 1966-15 June 1967, 10 U.N. GAOR, Supp. (No. 1A) 14-15, U.N. Doc. A/6701/Add. I (1967).

22. The Committee which drafted Chapter VI of the Charter, on the Security Council's peaceful settlement function, indicated in the record that recommended settlements would have no binding force. Doc. 1027, III/2/31 (1), 12 U.N.C.I.O. Docs. 159, 162 (1945). The Committee which drafted Chapter VII, on the collective measures function, indicated that if the Council were to attempt peaceful settlement of disputes of the more serious category justifying collective measures (i.e., aggressions, other breaches of peace and threats to peace) the procedures employed should be those defined in Chapter VI on peaceful settlement. Doc. 881, III/3/46, 12 U.N.C.I.O. Docs. 502, 507 (1945). The subject was also clarified in, The Charter of the United Nations: Hearings on the Charter of the United Nations Before the Senate Comm. on Foreign Relations, 79th Cong., 1st Sess. 279 (1945) (statement of Leo Pasvolsky).

23. Report of the Special Rapporteur of the Human Rights Commission, U.N. ESCOR, U.N. Doc. E/CN. 4/949/Add. 4, 494, 497 (1968). 
This indicates that some authority must be capable of deciding gross violations of human rights. Also, the assertion of a right to condemn implies a right to decide. The Charter provides no such powers of decision by nonjudicial organs or of condemnation. The statement also indicates that sanctions can be employed to deal with violations of human rights whereas, under the Charter, such measures can be employed only to deal with breaches of peace and threats to peace. This report was later endorsed by the Commission on Human Rights. ${ }^{24}$ In the same year, the United States representative on the Human Rights Commission said that, "the Commission should not condemn any [g]overnment unless it had sufficient evidence." ${ }^{25}$ However, there is no power of condemnation found in the Charter, evidence or no evidence. Governments subscribing to the Charter chose not to subject themselves to this kind of action. To assert it, nevertheless, seems calculated to exacerbate relations and increase confusion as to what the true powers of the organization are.

Although I have yielded to the temptation to use human rights cases to illustrate the argument, this being the subject of our symposium, I am not suggesting that human rights cases be treated differently from others. The thesis has to do with the relevant potential of United Nations disputehandling resources per se.

I will conclude by commenting on several questions of practicality which is, of course, of the essence of the proposed course of action. It may appear impractical because it is different and some aspects are remote from customary thought.

One question of practicality might be whether on the basis of the United Nations record, it is not utterly impractical to conceive of using this organization with rationality and restraint. My answer would be that we do not know what the organization would be capable of, given the right kind of leadership. Past leadership has been, in large part, self-centered and frequently has sought agreement to overriding and distorting Charter limitations and rules. The right kind of leadership would bring all significant disputes before the organization and assure that they are handled in accordance with Charter powers agreed to be applicable to all.

A second question might be whether the advocated program would produce as high a proportion of successfully settled disputes as the traditional approach. The proposed system could not, in any case, produce a worse record than that produced by past practices and might prove better since governments and peoples might be more amenable to procedures held within agreed

24. Commission on Human Rights Res. 3, 2 U.N. ESCOR Supp. (No. 4) 146, U.N. Doc. E/4475, E/CN. 4/972 (1968).

25. 2 U.N. ESCOR, Commission on Human Rights (24th sess.) 62-63, U.N. Doc. E/CN. 4/S.R. 969,18 (1968). 
limits than to those seen as imposing powers ultra vires.

I am not suggesting that in a case like Katanga Province, for example, where the United Nations appeared to have success in carrying out a Council decision to suppress the secessionist regime, ${ }^{26}$ that the Council should merely have recommended what it wanted done. The world apparently accepted the existence of a threat to peace in the Congo, as it was then (now Zaire), and all that would have been required by a proper interpretation of the Charter would have been to make a bona fide effort to show that the military force was an exercise of the collective measures function designed to deal with the threat.

The Spanish case was different in that there was no visible threat to peace and there was a finding by a Security Council Committee that there was no such threat. ${ }^{27}$ Accordingly, there was no justification for sanctions and the United Nations action should have been limited to recommendation. The result could not have been worse than what actually happened, since the measures in the case failed and were withdrawn after a few years. ${ }^{28}$ The oppressive regime continued for another generation (until Franco's death) when it was replaced by one more concerned about democracy and human rights. Outside pressure failed in this case and the change, when it came, came clearly from within. The same must be true of other, recent favorable changes in the human rights practices of Portugal, Greece, and India, provided these prove durable.

The Rhodesian case, noted above, falls between the Katanga and Spanish cases in that a threat to peace, while it was almost invisible at the time sanctions were instituted, developed later. Of course, the case is still unsettled and any attempted assessment would be premature. However, it seems highly doubtful that the dispute was brought closer to peaceful solution by the United Nations actions, which appear to have decided it on its merits, and to have undertaken enforcement of the decision. To the contrary, they might have fueled the civil war that developed.

The Rhodesian case suggests a broader level on which questions of practicality may arise, namely the strangeness of any approach designed to achieve a new format of international relations. It is scarcely possible to anticipate bringing about such a change without encountering some problems and difficulties along the way. Suggestions, for example, that United Nations action in

26. The decision is readily inferrable from S.C. Res. 169, U.N. SCOR (Res. \& Dec, 1961) 3 , U.N. Doc. S/INF/16/Rev. I (1961). The military operation involving United Nations troops which immediately preceded and seemed to bring about the collapse of the Katanga regime is briefly sketched in Annual Report of the Secretary-General on the Work of the Organization, 16 June 1962-15 June 1963, 18 U.N. GAOR SuPP. (1), at 8-11, U.N. Doc. A/5501 (1963).

27. Report of the Sub-Committee on the Spanish Question, 4 U.N. SCOR, Special Supp. (Rev. Ed.) 8 (1946).

28. G.A. Res. 386.8 U.N. GAOR Supp. (no. 20) 16, U.N. Doc. A/1775 (1950). 
the initial stage of the Rhodesian case should have been limited to discussion and recommendation would have encountered protests and demands that any alleged rules to this effect be set aside in the interests of justice. There is no history of efforts to apply such rules dispassionately based on agreed to principles-principles which, in a better world, might be called basic legal or constitutional principles.

Some apparent risks and sacrifices might be anticipated at this and a higher level where the goal being sought - the building of a world consensus that would rule out the possibility of intractable and unmanageable disputes -would entail necessarily some modification in the basic ideologies of some major powers. Some regimes might thus feel threatened and consequently endanger world security.

These questions of practicality should be compared with the dangers to which the world is subjected by its present political environment and the downward spiral of insecurity which seems to be part of it.

The present plan would seek to bring the world's differences into a marketplace of ideas. No country that believes in its own system and ideology would hesitate to accept such a challenge. Since nothing in this proposal goes beyond the rules and procedures deliberately agreed to by states as applicable to themselves, it seems that risks to individual states and dangers of international upheavals would be minimized. Although the successful development of consensus would necessitate some changes, these would be woven gradually into the social, cultural and political fabric of states through the debating process and attendant factors, so they could be expected to be incremental and virtually imperceptible.

The thesis presented by this article is, first, the proposition that human rights observances cannot be improved significantly by international action directed at the human rights problem per se. This problem lies close to the heart of the core problem of international relations and shares its intractability. The core problem can be defined for present purposes as the division of the world's peoples into separate communities and the corollary absence of such an overall community as would obviate the emergence of intractable disputes of such importance that might lead to war. Progress toward the building of the requisite degree of community would entail, also, progress toward improved human rights observances. It is submitted that progress toward these goals would be made if all significant disputes would be brought into the United Nations for a long period of time, and handled there in accordance with relevant Charter provisions agreed to be applicable to all. 